Discussion Paper No. 08-024

\title{
Voter Involvement, Fiscal Autonomy and Public Sector Efficiency: Evidence from German Municipalities
}

Benny Geys, Friedrich Heinemann, and Alexander Kalb

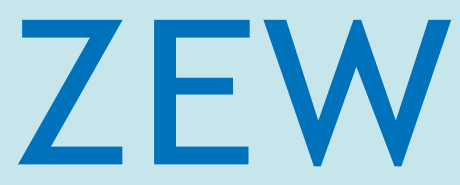

Zentrum für Europäische Wirtschaftsforschung $\mathrm{GmbH}$

Centre for European

Economic Research 
Discussion Paper No. 08-024

\title{
Voter Involvement, Fiscal Autonomy and Public Sector Efficiency: Evidence from German Municipalities
}

\author{
Benny Geys, Friedrich Heinemann, \\ and Alexander Kalb
}

Download this ZEW Discussion Paper from our ftp server:

ftp://ftp.zew.de/pub/zew-docs/dp/dp08024.pdf

Die Discussion Papers dienen einer möglichst schnellen Verbreitung von neueren Forschungsarbeiten des ZEW. Die Beiträge liegen in alleiniger Verantwortung der Autoren und stellen nicht notwendigerweise die Meinung des ZEW dar.

Discussion Papers are intended to make results of ZEW research promptly available to other economists in order to encourage discussion and suggestions for revisions. The authors are solely responsible for the contents which do not necessarily represent the opinion of the ZEW. 


\section{Non-Technical Summary}

Over the last 15 years, a rapidly-expanding body of literature has developed in which it is argued that 'social capital' positively affects institutional performance. Engagement in social life is argued not only to increase interest in and understanding of politics, but also to make one more willing and effective in demanding 'good' government. Clearly, however, two crucial assumptions have to be met for this argument to hold. Firstly, social engagement should foster political awareness and interest. Secondly, this increased interest and involvement in the political sphere should increase the performance of the incumbent government. While there are several researchers who provide evidence for the first assumption, the validity of the second assumption has received much less attention thus far.

The present paper takes a first step to bridge this gap. Using a broad panel of German municipalities we empirically investigate whether voters' political involvement which can be interpreted as a specific facet of the 'social capital complex' improves government performance. We thereby define good government performance as higher efficiency of public service provision or, more negatively, as a reduction in budgetary slack or rent-seeking. The efficiency measure employed is based on the public sector as a whole, rather than concentrating on efficiency in a given area of public good provision: e.g. waste collection, administration, road maintenance, and so on. Moreover, we assess how the participationefficiency nexus is affected by the degree of local fiscal autonomy. Fiscal autonomy is a crucial intervening variable since it implies that voters are effectively confronted with the tax bill for their desires.

The empirical results show that higher voter involvement - measured by (1) voter turnout, (2) the existence of so called 'free voter unions' in the local council (=local political associations that explicitly reject the idea of being linked to one of the traditional political ideologies), and (3) the ratio of eligible voters to total population - is indeed associated with increased government (technical) efficiency. Moreover, in line with our theoretical predictions, this effect is stronger in communities that have a higher degree of fiscal autonomy. One explanation for the last result is that an active citizenry is likely to put more weight on the careful (i.e. cost-efficient) use of public money when these public funds originate from own revenue sources rather than external transfers. 


\section{Zusammenfassung}

In den letzten 15 Jahren hat sich ein Literaturstrang entwickelt, der den positiven Einfluss von Sozialkapital auf das Leistungsverhalten des öffentlichen Sektors herausstellt. Danach erhöht das Engagement der Bürger im gesellschaftlichen Leben nicht nur das Interesse an sowie das Verständnis für Politik, sondern es führt auch dazu, dass die Bürger eher dazu neigen, eine „gute“ und effiziente Politik einzufordern. Diese Aussage besitzt jedoch nur dann Gültigkeit, wenn zwei entscheidende Annahmen erfüllt sind: Zum einen sollte das soziale Engagement das politische Bewusstsein und Interesse wecken, zum anderen sollte die erhöhte Anteilnahme sowie das erhöhte Interesse an politischen Prozessen zu einer Steigerung der Effizienz der Amtsinhaber oder der amtierenden Regierung führen. Während die erste Annahme bereits in zahlreichen Untersuchungen belegt wurde, wurde die zweite Annahme bisher nur in sehr wenigen Arbeiten untersucht.

Dieser Beitrag stellt den Versuch dar, diese Lücke zu schließen. Mithilfe eines umfangreichen Panels von deutschen (baden-württembergischen) Gemeinden wird in dieser Studie empirisch untersucht, ob eine erhöhte Anteilnahme der Bürger an politischen Prozessen - was als ein Teilaspekt des gesamten „Sozialkapital-Bereichs“ angesehen werden kann - das Leistungsverhalten des öffentlichen Sektors tatsächlich erhöht, wobei ein „gutes“ Leistungsverhalten (hier) dadurch charakterisiert ist, dass die jeweilige Gebietskörperschaft auf oder sehr nahe an ihrer Effizienzgrenze operiert. Die Effizienzanalyse bezieht sich dabei auf die Gesamtheit aller Aufgaben einer Gebietskörperschaft (hier: einer Gemeinde) und nicht auf einzelne Teilbereiche wie beispielsweise der Abfallbeseitigung, der Verwaltung oder des Straßenbaus. Des Weiteren wird in dieser Studie untersucht, wie sich eine erhöhte Anteilnahme an politischen Prozessen in Gebietskörperschaften, die durch eine höhere fiskalische Autonomie gekennzeichnet und somit weniger von Finanzzuweisungen abhängig sind, auf die Effizienz auswirkt. Denn Bürger (oder Wähler), die in fiskalisch autonomeren Gebietskörperschaften wohnen, werden effektiver mit dem „tatsächlichen“ Steuerpreis der öffentlichen Güter und Dienstleistungen konfrontiert.

Die empirische Analyse zeigt, dass eine erhöhte Anteilnahme der Bürger an politischen Prozessen - gemessen durch (1) die Wahlbeteiligung, (2) die Existenz so genannter „Freier Wählervereinigungen“ im Gemeinde- oder Stadtrat (=Zusammenschlüsse von Personen, die Zwecks Durchsetzung gemeinsamer politischer Ziele zu einer Wahl auf kommunaler Ebene 
antreten) und (3) den Anteil der Wahlberechtigten an der Gesamtbevölkerung (einer Gemeinde) - tatsächlich zu einer Steigerung der Effizienz der Amtsinhaber führt. Darüber hinaus wird aufgezeigt, dass dieser Effekt in fiskalisch autonomeren Gemeinden bzw. Städten deutlich höher ausfällt. Letzteres Ergebnis könnte dadurch begründet sein, dass eine (politisch) aktivere Bürgerschaft mehr Wert auf eine korrekte und sachgerechte Verwendung der öffentlichen Mittel legt, wenn diese Gelder nicht etwa in Finanzzuweisungen (von anderen Gebietskörperschaften) ihren Ursprung haben, sondern von eigenen Steuereinnahmen abstammen. 


\title{
Voter Involvement, Fiscal Autonomy and Public Sector Efficiency: Evidence from German Municipalities
}

\author{
Benny Geys ${ }^{\mathrm{a}}$, Friedrich Heinemann ${ }^{\mathrm{b}}$, Alexander Kalb ${ }^{\mathrm{c}, *}$ \\ ${ }^{a}$ Wissenschaftszentrum Berlin für Sozialforschung (WZB), "Market Processes and Governance" \\ Research Unit, Reichpietschufer 50,D-10785 Berlin, Germany; e-mail: geys@wzb.eu \\ ${ }^{\mathrm{b}}$ Zentrum für Europäische Wirtschaftsforschung (ZEW), "Corporate Taxation and Public Finance" \\ Research Unit, L 7, 1, D-68161 Mannheim, Germany; e-mail: heinemann@zew.de \\ ${ }^{c}$ Zentrum für Europäische Wirtschaftsforschung (ZEW), "Corporate Taxation and Public Finance" \\ Research Unit and University of Heidelberg; e-mail: kalb@zew.de
}

April 2008

\begin{abstract}
:
Social and/or political involvement within the population is often argued to enhance public sector performance. The underlying idea is that engagement fosters political awareness and interest and increases the public's monitoring ability. Still, although extensive voter involvement may put pressure on policy-makers, it might also send a vague message in that diverging objectives are likely to exist in different groups. Furthermore, weak fiscal autonomy can undermine voters' interest in and demand for an efficient production of public services. In our contribution, we test whether and how voter involvement in the political sphere is related to government performance - in terms of its efficiency - using a broad panel of German municipalities. Our results suggest that voter involvement indeed has a positive impact on (technical) efficiency. Crucially, however, this efficiency-enhancing effect of voter involvement is significantly (positively) affected by local governments' fiscal autonomy.
\end{abstract}

Keywords: Civic engagement; Local government; Efficiency; Stochastic frontier analysis; German municipalities; Social capital; Fiscal autonomy

JEL Classification: H11, H40

Acknowledgements: We would like to thank Lars-Erik Borge and Per Tovmo for very helpful comments and suggestions. Support by the German Research Foundation (DFG) within its Priority Programme 1142 "Institutionelle Gestaltung föderaler Systeme" is gratefully acknowledged.

\footnotetext{
* Corresponding author

Centre for European Economic Research (ZEW)

L7, 1, D-68161 Mannheim, Germany
}

\author{
Phone: +496211235282 \\ Fax: $\quad+496211235223$ \\ E-mail: kalb@zew.de
}




\section{Introduction}

Over the last 15 years, a rapidly-expanding body of literature has developed in which it is argued that 'social capital' positively affects institutional performance (e.g., Putnam, 1993; Cusack, 1999; Bjørnskov, 2003; Coffé and Geys, 2005). One of the theoretical arguments brought forward to explain this relation is that civic engagement increases performance "to the extent that it makes citizens sophisticated consumers of politics" (Boix and Posner, 1998, 690). Engagement in social life is argued not only to increase interest in and understanding of politics, but also to make one more willing and effective in demanding 'good' government. Clearly, however, two crucial assumptions have to be met for this argument to hold. Firstly, social engagement should foster political awareness and interest. Scheufele et al. (2004), among others, provide some evidence that this is indeed the case. Secondly, this increased interest and involvement in the political sphere should increase the performance of the incumbent government. The validity of this 'assumption', however, has received much less attention thus far and was recently even described as a "plausible, important but insufficiently tested proposition" (Toka, 2008, 31).

The present paper takes a first step to bridge this gap. It empirically assesses whether voters' political involvement (which can be interpreted as a specific facet of the 'social capital complex') improves government performance. We thereby define good government performance as higher efficiency of public service provision (or, more negatively, a reduction in budgetary slack or rent-seeking). ${ }^{1}$ The efficiency measure employed is based on the public sector as a whole, rather than on a given area of public good provision: e.g. waste collection, administration, road maintenance, and so on (e.g., Kalseth and Rattsø, 1998; De Borger and Kerstens, 2000). This 'global' approach is appropriate when "the explanatory variables characterize the local government institution rather than being sector-specific" (Borge et al., $2007,2)$ - as is here the case. In such a setting, concentrating on "one particular element of service provision may be inadequate (or even misleading)" (Ashworth et al., 2007, 12).

While numerous studies examine local government efficiency and its determinants (e.g., De Borger et al., 1994; De Borger and Kerstens, 1996; Worthington, 2000; Geys, 2006; Balaguer-Coll et al., 2007; Geys and Moesen, 2007a, b), only one of these includes a measure of political involvement (i.e., Borge et al., 2007). The present study adds to this previous

As such, we differ from most of the 'social capital' literature, which often relies on a relatively inclusive and elusive - 'factor' of institutional performance (e.g. Putnam, 1993; Serra, 1999; Casey, 2004). 
literature in three main ways. First, we analyse a broad set of indicators of voter involvement (thus going beyond electoral turnout as a measure of citizen involvement; cfr. Borge et al., 2007). As such, we are able to examine how different ways through which voters get politically involved affect government performance. Second, we are - to the best of our knowledge - the first to assess how the participation-efficiency nexus is affected by the degree of local fiscal autonomy. Fiscal autonomy (in contrast to dependence on external grants) is a crucial intervening variable since it implies that voters are effectively confronted with the tax bill for their desires. An active citizenry is likely to put more weight on the careful use of public money which originates mainly from own revenue sources rather than external transfers. Third, our empirical analysis is based on a broad panel of German municipalities (rather than a cross-section of Norwegian municipalities; cfr. Borge et al., 2007). This not only provides us with a larger dataset, but also allows us to analyze the participation-efficiency nexus in a different political and institutional setting. As the determinants of (local) government efficiency have not been studied before using German data, our results are of wider interest for comparative purposes.

The remainder of the article is structured in four main parts. The first of these presents the theoretical background and hypotheses upon which the later empirical analysis builds. Section 3 then introduces the German institutional and political setting. The empirical analysis is provided in section 4. Previewing the results, we show that higher voter involvement is indeed associated with increased government (technical) efficiency. Moreover, in line with our theoretical predictions, this effect is stronger in communities that have a higher degree of fiscal autonomy. Finally, section 5 reiterates the main findings of our study and discusses some implications.

\section{Theoretical background and hypotheses}

From a theoretical perspective, the link between voter involvement and (the efficiency of) public policy can be analysed in a principal-agent setting (cfr. Migué and Bélanger, 1974; Niskanen, 1975; Borge et al., 2007). Local government officials act as agents for the population, who - as principals - desire the government to provide as many public goods as possible for a fiscal cost that is as low as possible. That is, "voters want more competent politicians in office, as they can provide more public goods for given levels of taxation and private consumption" (Alt and Lassen, 2006, 1404; see also Shi and Svensson, 2006). However, there is a clear conflict of interest in that politicians (or bureaucrats) in charge of 
public goods provision may (personally) benefit from less productive activities: e.g. higher salaries, lower effort, over-employment within their particular service, and so on. Given that politicians (or bureaucrats) tend to be better informed about the true cost of providing public goods than the general population, there exists an incentive to 'invest' in such less-productive activities. These, however, induce ‘budgetary slack' (or inefficiency).

Importantly, the extent of budgetary slack is likely to be significantly affected by the institutional setting. One crucial element in this respect is whether or not the principal assumes an active role in informing himself about and supervising the actions of his agent. When the agent is involved, "budgetary slack can be reduced" (e.g. Moene, 1986; Chan and Mestelman, 1988). Building on this argument, we contend that political involvement of voters is one means to actively monitor political agents. Participating citizens have indeed been argued to be more critical, better informed and more vigorous in demanding particular policies (cfr. Boix and Posner, 1998; Scheufele et al., 2004). For example, (voluntary) organisations often attempt to influence the political process (see Schattschneider, 1960; Olson, 1965) or are involved in the implementation of such policies (e.g. football fan clubs in the UK are explicitly involved in policy initiatives to combat hooliganism). A more active citizenry increases the pressure on government officials and thereby increases their effort levels. To the extent that higher effort enhances performance, a first hypothesis can be stated as follows.

HYP 1: Higher voter involvement increases local government performance (i.e. efficiency)

A first important qualification is that the conclusion drawn above depends on having one median voter (and a homogenous group of residents). In real life, however, the populace generally cannot adequately be described as having homogenous preferences. Conflicting demands are likely to exist and agreement on what 'good' government entails is implausible (see, for example, Olson, 1982). Extensive voter involvement may then well put pressure on policy-makers, but might also create a vague message. The result is that, when expressed in greater amounts, such conflicting demands might even reduce performance.

HYP 2: Higher voter involvement impairs local government performance (i.e. efficiency) 
A second caveat refers to fiscal institutions. Indeed, Hypothesis 1 rests on the assumption that voters desire efficiency. This assumption, however, is only likely to hold when they are confronted with the tax bill for public goods provision (since inefficient production of public services increases the tax bill without a concomitant increase in services obtained). This, in turn, depends on whether fiscal institutions are built on the principle of fiscal equivalence (Olson, 1969) and imply a high (or perfect) mapping of citizens who consume and finance public services. In the presence of a 'mismatch', voters' function as efficiency guards may be impaired because it is other people's money that is being wasted. From the literature on the "flypaper effect" (Heyndels and Smolders, 1994; Hines and Thaler, 1995; Heyndels, 2001) it is well known that money which a jurisdiction obtains from lump-sum grants is used differently than money from own tax sources. In fact, while economic theory would suggest that an increase in revenues from both sources is equivalent and has similar implications on the jurisdiction's spending pattern, unconditional grants are de facto more likely to be used for additional spending rather than tax cuts. Voters thus appear to put less weight on the careful use of public money originating from external transfers. This suggests that in transferdependent municipalities with low fiscal autonomy, high voter involvement may result in spending pressure and need not be associated with higher efficiency. This leads us to our third and final hypothesis:

HYP 3: The effect of voter involvement on local government performance (i.e. efficiency) is mediated by the degree of local fiscal autonomy

\section{German local political and fiscal setting}

Baden-Württemberg lies in the southwest of Germany (bordering France and Switzerland) and is the third largest of the 16 German federal states - both in terms of its surface area and its number of inhabitants. Its 10.7 million inhabitants are distributed among 1109 municipalities $^{2}$ which currently range in size from about 100 to almost 600.000 inhabitants. Each of these municipalities is governed by a local council (elected for five-year terms) and a directly elected mayor (with an eight-year term). The mayor acts as the chairman of the

\footnotetext{
2 Since 1975 Baden-Württemberg consisted of 1111 municipalities. In 2006 and 2007, however, there were two mergers so that the number of municipalities decreased to 1109.
} 
municipal council and has significant agenda-setting powers. Both council and mayor have their own statutory responsibilities, which are the same across all municipalities. ${ }^{3}$

At the state level, Baden-Württemberg is a traditional stronghold of the Christian Democrats (CDU). Since the state's inception in 1952, the state government has generally been led by CDU prime ministers, often as one-party governments (the sole exception is the 1952-53 government under liberal prime-minister Reinhold Maier). At the municipal level, the CDU has been almost equally dominant (see Table 1). Still, unlike state or federal elections, local elections in Baden-Württemberg are also characterized by the increasing importance of socalled "free voters unions" ("Freie Wählervereinigungen"). The latter can be seen as an indicator of local voter involvement. The reason is that they are a grassroots type of organization that is the result of local initiatives. They are not linked to one of the traditional political ideologies and even explicitly reject the idea of constituting a political party. Also, no national organization of free voters exists that initiates the foundation of free voter unions at the local level. While in some cases they do form networks at the state level, these local groups are independent (and tend to focus on specific affairs within their municipality).

Table 1: Results of local council elections in Baden-Württemberg (\% of valid votes)

\begin{tabular}{|l|ccccccc|}
\hline & \multicolumn{7}{|c|}{ Election year } \\
& $\mathbf{1 9 7 5}$ & $\mathbf{1 9 8 0}$ & $\mathbf{1 9 8 4}$ & $\mathbf{1 9 8 9}$ & $\mathbf{1 9 9 4}$ & $\mathbf{1 9 9 9}$ & $\mathbf{2 0 0 4}$ \\
\hline CDU (Christian Democrats) & 38.9 & 39.6 & 37.9 & 32.6 & 31.6 & 36 & 33.2 \\
SPD (Social Democrats) & 29.2 & 30.2 & 26.3 & 25.6 & 24.1 & 21.7 & 19.9 \\
FDP/DVP (Liberals) & 5.5 & 5.3 & 3.9 & 4.6 & 3.5 & 3 & 3.7 \\
GRÜNE (Greens) & 0 & 1.7 & 6.3 & 5.9 & 7.7 & 5.2 & 8.2 \\
Wählervereinigungen & & & & & & & \\
(Voters' unions) & 19.9 & 18.3 & 21.6 & 23.6 & 26.6 & 27.5 & 29.4 \\
Other & 6.5 & 4.9 & 4 & 7.7 & 6.5 & 6.6 & 5.6 \\
\hline
\end{tabular}

Source: Statistical Office Baden-Württemberg

One other institutional characteristic of the Baden-Württemberg municipalities that is of importance for our purpose concerns their degree of fiscal autonomy. German municipalities in general have some - albeit limited - leeway in generating own revenues. To see this, a brief look at their revenue structure is required. Most basically, revenues derive from three main sources: tax revenue (on average $41 \%$ of total municipal revenues in 2004), allocation of funds (through, for example, fiscal equalization schemes) (31\%) and revenue from user

\footnotetext{
${ }^{3}$ Contrary to the state or federal level, the formation of governing majorities within the local council is not institutionalized in the local law of Baden-Württemberg. Nonetheless, their existence is uncontested. Interparty cooperations are used to facilitate and, to some extent, control opinion formation and decision-making.
} 
charges (9\%) (see figure 1(1)). ${ }^{4}$ Among the tax revenues, however, a substantial part (i.e. $42 \%$ ) originates from shared taxes (i.e. income tax and VAT) decided upon by the federal and state-level governments. Local governments can only independently decide on five types of taxes (although the federal government even here often sets a regulatory 'framework'): trade tax (“Gewerbesteuer”), property tax (“Grundsteuer”), tax on keeping dogs, second residence tax and entertainment tax. Only the first two of these yield significant revenues $(41 \%$ and $15 \%$ of total tax revenues in 2004 respectively, see figure 1(2)). ${ }^{5}$ Overall, revenues from fiscal equalization schemes and shared taxes (over which the municipalities have no control) constitute about half of the municipal revenues and thereby far outweigh revenues from autonomously determined tax sources. Hence, though some leeway exists in generating own revenues, the extensive tax sharing and fiscal equalization payments limit local governments' budgetary autonomy and responsibility.

Figure 1: Structure of the total revenue (1) and composition of tax revenue (2) for all municipalities in Baden-Württemberg in 2004
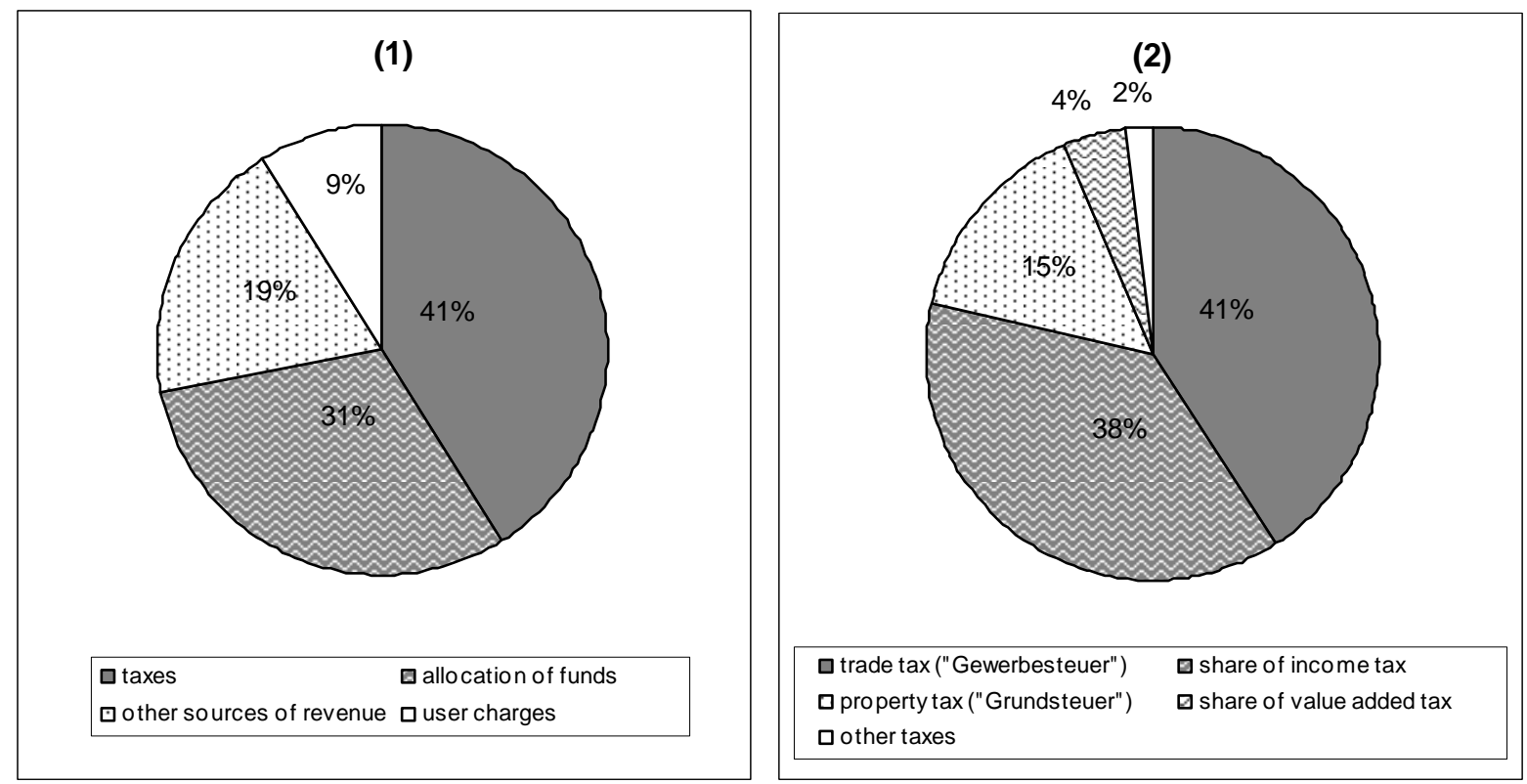

Source: Ministry of Finance of Baden-Württemberg (2006)

Still, and importantly, the degree of fiscal autonomy varies across municipalities in BadenWürttemberg. We more specifically distinguish between two types of municipalities based on their requirement to receive 'key grants' (“Schlüsselzuweisungen”) under the horizontal (i.e. inter-municipal) fiscal equalization scheme. This horizontal element of the fiscal equalization

\footnotetext{
4 Note that the numbers do not fully sum to $100 \%$. Other (minor) sources of revenue include administrative revenue, shares in profits, concession levy, support for debt service and sales revenues.

5 Nevertheless, the most important autonomous tax source - the trade tax - is not paid by voters in general, but only by larger local firms (smaller firms are tax-exempt due to tax thresholds).
} 
scheme tries to balance communities' economic prowess by comparing the financial 'power' and 'requirements' of each municipality and giving 'key grants' to financially weak municipalities. ${ }^{6}$ Obviously, awarding such 'key grants' to a municipality increases its grantdependence and reduces its fiscal autonomy. This allows us to distinguish between 'independent' municipalities that obtain no 'key grants' and 'dependent' municipalities that do receive such grants. In 2004 'independent' municipalities made up approximately $9.4 \%$ of all communities.

\section{Empirical analysis}

\subsection{Model specification}

Our analytical strategy is to identify the impact of voter involvement on municipalities' overall cost efficiency. For that purpose, we build on the stochastic, parametric approach to efficiency measurement developed by Aigner et al. (1977) and Meeusen and van den Broeck (1977). Most generally, and using a translogarithmic specification (cf. Christensen et al., 1973), the empirical model can be written as (dropping subscripts for decision-making units for convenience):

$$
\ln C=\alpha+\sum_{r=1}^{s} \beta_{r} \ln y_{r}+\frac{1}{2} \sum_{r=1}^{s} \sum_{q=1}^{s} \lambda_{r q} \ln y_{r} \ln y_{q}+\underbrace{v+u}_{=\varepsilon}
$$

where $\mathrm{C}$ designates the input indicator (which in effect can be interpreted as the money equivalent of multiple inputs), $y$ indicates the various output indicators, $s$ points to the number of outputs incorporated in the model and $\beta_{\mathrm{r}}$ and $\lambda_{\mathrm{rq}}$ are parameters to be estimated. ${ }^{7}$ The advantage of such a parametric approach is that it allows distinguishing measurement error from inefficiency (which is not possible in non-stochastic methods such as FDH) ${ }^{8}$ This is achieved through a composed error term consisting of a symmetric component $(v)$ (assumed white noise) and a one-sided non-negative component $(u \geq 0)$ representing inefficiency. These error components are assumed to be independent.

6 The municipal fiscal equalization scheme incorporates both vertical and horizontal elements. The vertical part is concerned with the financial relationship between the state (i.c. Baden-Württemberg) and its municipalities. Note that in 2004, 'key grants' made up roughly $50 \%$ of the whole fiscal equalization mass ("Finanzausgleichsmasse").

7 This is a more general functional form than the traditional Cobb-Douglas function. Specifically, in a CobbDouglas specification, all squared values and cross-product terms are excluded. Statistical tests (not reported) indicated that the coefficients $\lambda_{\text {rq }}$ are jointly significantly different from 0 (and, therefore, that the translogarithmic functional form is to be preferred to a Cobb-Douglas specification).

8 The FDH (free disposable hull) approach belongs to the class of non-parametric efficiency measurement methods, for a survey see Lovell (1993). 
Importantly, the influence of exogenous (or non-discretionary) influences that might shape local government performance can be introduced into the model above. This is important since certain characteristics of a municipality - such as the extent to which voters are involved in the political process - may affect how efficiently the local government is in carrying out its tasks (Battese and Coelli, 1995; Stevens, 2004). To accommodate such elements, we assume that the inefficiency term $(u)$ in equation (1) is a function of a set of community characteristics (cfr. Battese and Coelli, 1995). In other words, and as discussed in Coelli $(1996,7), u$ is "assumed to be independently distributed as truncations at zero of the $N\left(m_{i}\right.$, $\sigma_{u}^{2}$ ) distribution where $m_{i}=\delta z_{i}$ ". In this extension, $z_{i}$ is a vector of background variables which are expected to influence (in)efficiency and $\delta$ is a vector of parameters to be estimated. This leads to the following model to be estimated:

$$
\begin{gathered}
\ln C_{i, t}=\alpha+\sum_{r=1}^{s} \beta_{r} \ln y_{r, i, t}+\frac{1}{2} \sum_{r=1}^{s} \sum_{q=1}^{s} \lambda_{r q} \ln y_{r, i, t} \ln y_{q, i, t}+v_{i, t}+u_{i, t} \\
u_{i, t}=\gamma+\sum_{j=1}^{J} \delta_{j} z_{j, i, t}+w_{i, t},
\end{gathered}
$$

where $i$ is the subscript for decision-making units (local governments) and $t$ the time subscript. The error term of equation (3), w, is defined by the truncation of the normal distribution with zero mean and variance $\sigma^{2}$ (Battese and Coelli, 1995). The latter assumption assures that the inefficiency component $u$ can only take values bigger than or equal to zero.

Before turning to the presentation of the input, output and background variables employed below, it should be mentioned that heterogeneity of factor costs across jurisdictions might complicate our analysis. Fortunately, in our setting, factor price divergence is limited since labour and capital costs are largely identical for the municipalities of Baden-Württemberg. Interest rate homogeneity exists because all municipalities have access to the same capital market in the same currency and the German constitution implies a full bail-out guarantee for all public entities (leading to the absence of risk premium differences across German jurisdictions). Broadly similar wages are guaranteed via a uniform collective labour agreement for the state's public sector.

\subsection{Data and explanatory variables}

The definition and measurement of public sector outputs is notoriously difficult and fraught with data availability problems (cfr. Levitt and Joyce, 1987; De Borger and Kerstens, 1996). Hence, in line with previous analyses of local government efficiency, we are forced to rely on 
proxies. To allow for maximum comparability, we thereby follow previous work in this field to determine which input and output variables to include in the analysis (e.g. Vanden Eeckaut et al., 1993; De Borger et al., 1994; De Borger and Kerstens, 1996; Geys and Moesen, 2007a, b). We thereby rely on data for 987 municipalities in the German state Baden-Württemberg for the 3-year-period 1998, 2002 and 2004 (data availability precluded the use of the remaining 124 municipalities).

Our prime input variable (C) is total municipal (net) current primary expenditures. These include all spending on the current budget minus the difference between debt service and income from interest. We do not include capital spending as this mainly refers to investment spending, which depends on when such projects are agreed upon (and thus tends to inflate spending in the years such projects occur).

Local public good provision (i.e. our outputs $y$ ) is measured through six variables tapping into various important responsibilities of the German local governments with respect to social needs, education, recreation and infrastructure: (a) the number of students in local public schools ("Grund- and Hauptschulen"), (b) the number of kindergarten places, ${ }^{9}$ (c) the surface of public recreational facilities, (d) the total population, (e) the population over age 65 , and (f) the number of employees paying social security contributions. As mentioned, some of these measures should be considered as, at best, rather crude proxies for the level of public goods provision (see also De Borger et al., 1994; De Borger and Kerstens, 1996). Population, for example, proxies the extent of administrative tasks (such as issuing various types of documents) whereas the share of elderly indicates service provision to the elderly (e.g., retirement homes). Neither, however, is a direct output variable. Therefore, as in previous work on local government efficiency, "the outputs used are rather loosely related to the services delivered by municipal governments" (De Borger and Kerstens, 1996, 153-154).

The crucial part of the model refers to the background variables we introduce in the vector $z_{i, t}$. These are of two kinds: namely, measures for voter involvement and 'other' controls. To start with the former - as they intend to test our core hypotheses - we introduce three measures indicating the extent of voters' political involvement in the municipality. These capture

9 Only the total number of public and private kindergarten places of the years 1998 and 2002 was available. We therefore took the data of 2002 to approximate the kindergarten places of the year 2004. Moreover, it would be preferred to use only the number of public kindergarten places; the addition of private kindergartens, however, may not be overly problematic. The reason is that these places also imply an 'organisational' burden for the local government. 
various means through which voters are able to voice their concerns to politicians, and may affect efficiency in differing ways.

- The first measure of political involvement is voter turnout (defined as the number of votes cast relative to the total municipal population). Voter turnout is strongly positively related to people's interest in and knowledge of politics (e.g., Squire et al., 1987; Brady et al., 1995). As such, high turnout indicates a politically interested electorate that has the ability (in terms of knowledge and interest) and desire (given that it actively turns out to vote) to supervise its politicians and make their preferences known. Whether this affects efficiency in a positive (cfr. Hypothesis 1) or negative (cfr. Hypothesis 2) way depends on the extent to which preferences within the population are homogenous (see above).

- The second measure of voter involvement is an indicator variable for the existence of free voter unions. As argued in section 3, the existence of free voter unions indicates that (at least some) citizens are ready to incur the cost of organization to resolve certain local policy issues. Since free voter unions cannot rely on support from a state- or country-wide party apparatus, personnel and financial resources, their members must feel sufficiently politically involved to create such an organisation. The direction of their effect on efficiency is once again a priori uncertain. On the one hand, their presence could benefit municipal efficiency given the beneficial role - discussed in the extensive social capital literature - of associational life for numerous socio-political and economic outcomes (Putnam 1993; Stolle and Rochon, 1998; Paxton, 2002; Coffé and Geys, 2007a, b; Geys, 2008). On the other hand, the economic literature on special interest groups suggests the reverse effect since accommodation of special interest groups might also lead to less efficient policies (e.g. Mueller and Murrell, 1986).

- Our third and final measure of voter involvement is the share of eligible voters to total population. This captures the extent to which inhabitants of a given municipality are able to control their politicians through the ballot box (not the extent to which they actually do, which is captured by the voter turnout measure above). When a substantial share of taxpayers has no voting rights (e.g. because they are of non-EU nationality), popular intervention through the electoral process is likely to be reduced. However, given the heterogeneity of voter preferences, this might not necessarily be a bad thing with respect to its efficiency impact (cfr. Hypothesis 2).

To assess how the degree of fiscal autonomy affects the involvement-efficiency nexus (cfr. Hypothesis 3), we interact each of the above measures with a dummy variable for 
'independent' communities (see section 3). Since these municipalities exhibit the highest degree of fiscal autonomy - making the tax price for local expenditures more visible - we expect that the effect of voter involvement is stronger in these municipalities. The reason, as mentioned, is that citizens are likely to put more weight on the careful use of public money which originates from own revenue sources than from external transfers. Hence, a more active citizenry is more likely to be a force for efficiency in fiscally more 'independent' municipalities.

The second set of background variables included in the vector $z_{i, t}$ concerns various elements describing the municipality's production environment and the political constraints it faces. The production environment is accounted for through population density (measured as inhabitants per are) and the unemployment rate. While the former picks up the rural/urban divide (Stevens, 2005) and the heterogeneity of property prices (which might affect the cost situation of municipalities), unemployment implies higher spending on social benefits (a 'cost effect') as well as lower demand for high-cost (or high-quality) public services (a 'preference effect'). ${ }^{10}$ The political constraints are captured through a Herfindahl index measuring political concentration in the local council (higher concentration of power is expected to reduce efficiency; see also Ashworth et al., 2007) ${ }^{11}$ and the seat share of left-wing parties (i.e. SPD, Grüne). For the latter variable there are two interpretations. First, given that the Christian Democrats have a dominating position in Baden-Württemberg (see section 3), the share of the left-wing parties can be seen as an indicator of political competition. Second, however, it measures the impact of ideology. This ideological effect is not easy to determine a priori. While left-wing parties are often assumed to have a preference for a larger government size, this need not imply less efficient governments. Descriptive statistics for all variables are given in table 2 below.

10 Additional factors can be conceived here - such as the geographical location or territorial characteristics but lack of data makes inclusion of such factors difficult.

11 Technically, the Herfindahl index is measured as the sum of the squared seat shares of the main national parties (CDU, FDP, SPD, GRÜNE) and local parties. 
Table 2: Descriptive Statistics (987 municipalities over 3 years: 1998, 2002 and 2004)

\begin{tabular}{|c|c|c|c|c|}
\hline Variable & Mean & $\begin{array}{l}\text { Standard } \\
\text { Deviation }\end{array}$ & Minimum & Maximum \\
\hline \multicolumn{5}{|l|}{ Input variable: } \\
\hline $\begin{array}{l}\text { Net current primary expenditures } \\
\text { (in million euros) }\end{array}$ & 20.40 & 86.30 & 0.35 & 2890.00 \\
\hline \multicolumn{5}{|l|}{ Output variables: } \\
\hline Students in public schools & 662.14 & 1308.41 & 0 & 27126 \\
\hline Kindergarten places & 417.85 & 825.17 & 0 & 17554 \\
\hline Recovery area (in are) & 2480.27 & 5901.94 & 0 & 110841 \\
\hline Total population & 10525.13 & 26837.23 & 242 & 589231 \\
\hline Population older than 65 & 1747.26 & 4625.50 & 31 & 105289 \\
\hline $\begin{array}{l}\text { Number of social insured employees } \\
\text { (at place of work) }\end{array}$ & 3769.91 & 14788.02 & 10 & 355536 \\
\hline \multicolumn{5}{|l|}{ Voter involvement variables: } \\
\hline Voter turnout (in \%) & 63.219 & 8.337 & 37.216 & 88.736 \\
\hline Free voter unions & 0.957 & 0.203 & 0 & 1 \\
\hline $\begin{array}{l}\text { Ratio of eligible voters to total population } \\
\text { (in \%) }\end{array}$ & 73.122 & 3.307 & 60.978 & 99.753 \\
\hline \multicolumn{5}{|l|}{ Other control variables: } \\
\hline Unemployment rate (in \%) & 6.574 & 1.321 & 2.900 & 12.700 \\
\hline Population density (inhabitants per are) & 3.358 & 3.328 & 0.207 & 28.416 \\
\hline Herfindahl index & 0.515 & 0.247 & 0.211 & 1 \\
\hline $\begin{array}{l}\text { Share of left-wing parties (SPD+GRÜNE) } \\
\text { (in \%) }\end{array}$ & 17.838 & 14.680 & 0 & 65 \\
\hline 'Independent' municipalities & 0.082 & 0.275 & 0 & 1 \\
\hline
\end{tabular}

Source: Statistical Office of Baden-Württemberg

\subsection{Results}

The results - obtained by using FRONTIER 4.1 (Coelli, 1996) - are summarized in Table 3. The first three columns provide the results using our three different indicators of voter involvement separately. Column 4 includes all three involvement measures at the same time to check the robustness of the individual findings and assess how the relation between all three measures affects their respective findings. In the last three columns, we assess the mediating effect of fiscal autonomy by including interaction effects between voter involvement and fiscal autonomy. Before discussing our findings, it should be noted that the variance parameter gamma is close to one in all specifications and highly significant (see bottom row of table 3). This indicates that the majority of the variation in the composed error term is due to the inefficiency component, $u_{i, t}$ (see section 4.1). Moreover, one-sided generalized likelihood ratio tests of the inefficiency effects indicate that in all specifications the null hypothesis that the inefficiency effects are absent from the model(s) can be strongly rejected. This implies that all covariates of the inefficiency model (given in equation (3) 
above) are jointly significant. Hence, the stochastic frontier model we chose seems to be an adequate representation of the data.

To start the discussion of our findings with the control variables, table 3 clearly illustrates that it is important to account for the production and political environment in the municipality. Specifically, we first of all observe a negative sign with robust significance for the unemployment rate. This suggests that the preference-effect (i.e. relating to lower demand for high-quality public services among the unemployed) outweighs the cost-effect (i.e. higher spending on unemployment and housing benefits). Secondly, densely populated municipalities tend to be more efficient, suggesting they have a cost advantage from agglomeration economies. Thirdly, we show that a low degree of political competition - as indicated by a high Herfindahl index or, given the dominant position of the CDU in BadenWürttemberg, a low share of left-wing parties - is associated with lower efficiency. Political monopolies, in line with expectations, do not foster cost-efficient behavior within the municipal administration (see also Ashworth et al., 2007, for a similar finding in a different setting). Finally, the positive effect found for financially 'independent' municipalities suggests that these can afford more (or qualitatively higher) public goods and services due to their higher economic power. 
Table 3: Determinants of Baden-Württemberg's local government cost efficiency

\begin{tabular}{|c|c|c|c|c|c|c|c|}
\hline Variable & (1) & $(2)$ & $(3)$ & $(4)$ & $(5)$ & $(6)$ & $(7)$ \\
\hline \multicolumn{8}{|c|}{ Production environment and political constraints } \\
\hline Unemployment Rate & $\begin{array}{c}-0.0247 * * \\
(-3.5136) \\
\end{array}$ & $\begin{array}{c}-0.0514 * * \\
(-6.7206)\end{array}$ & $\begin{array}{c}-0.0439 * * \\
(-5.7417)\end{array}$ & $\begin{array}{c}-0.0365 * * \\
(-4.5828) \\
\end{array}$ & $\begin{array}{c}-0.0235 * * \\
(-2.5856) \\
\end{array}$ & $\begin{array}{c}-0.0490 * * \\
(-6.8962) \\
\end{array}$ & $\begin{array}{l}-0.0410 * * \\
(-4.3281) \\
\end{array}$ \\
\hline Population density & $\begin{array}{c}-0.0555^{* *} \\
(-6.3933)\end{array}$ & $\begin{array}{l}-0.0464 * * \\
(-7.4453)\end{array}$ & $\begin{array}{l}-0.0485 * * \\
(-7.4488)\end{array}$ & $\begin{array}{l}-0.0409 * * \\
(-5.9351)\end{array}$ & $\begin{array}{l}-0.0529 * * \\
(-5.8337) \\
\end{array}$ & $\begin{array}{l}-0.0468 * * \\
(-7.6972)\end{array}$ & $\begin{array}{l}-0.0447 * * \\
(-5.9409)\end{array}$ \\
\hline Herfindahl index & $\begin{array}{c}0.3453^{* *} \\
(5.0724)\end{array}$ & $\begin{array}{l}0.1254^{*} \\
(2.4019) \\
\end{array}$ & $\begin{array}{l}0.1264 * * \\
(2.6597)\end{array}$ & $\begin{array}{c}0.0036 \\
(0.0779) \\
\end{array}$ & $\begin{array}{c}0.3317^{* *} \\
(3.8551)\end{array}$ & $\begin{array}{l}0.1607 * * \\
(2.6988)\end{array}$ & $\begin{array}{l}0.1343^{*} \\
(2.0125)\end{array}$ \\
\hline Share of left & $\begin{array}{l}-0.0025^{*} \\
(-2.4930)\end{array}$ & $\begin{array}{l}-0.0090 * * \\
(-4.9833)\end{array}$ & $\begin{array}{c}-0.0015 \\
(-1.4163)\end{array}$ & $\begin{array}{c}-0.0058 * * \\
(-4.4367)\end{array}$ & $\begin{array}{c}-0.0015 \\
(-1.2759)\end{array}$ & $\begin{array}{c}-0.0090 * * \\
(-4.0450)\end{array}$ & $\begin{array}{c}-0.0005 \\
(-0.4546)\end{array}$ \\
\hline $\begin{array}{l}\text { Dummy independent municipality } \\
\text { (IM) }\end{array}$ & $\begin{array}{c}2.5062 * * \\
(6.1182) \\
\end{array}$ & $\begin{array}{c}2.2549 * * \\
(6.0632) \\
\end{array}$ & $\begin{array}{l}1.7430 * * \\
(7.6678) \\
\end{array}$ & $\begin{array}{l}1.6732 * * \\
(6.4256) \\
\end{array}$ & $\begin{array}{l}2.7270 * * \\
(5.3425) \\
\end{array}$ & $\begin{array}{l}3.3852 * * \\
(5.9887) \\
\end{array}$ & $\begin{array}{l}1.1467 * \\
(1.9620) \\
\end{array}$ \\
\hline \multicolumn{8}{|c|}{ Voter involvement } \\
\hline Voter turnout (VT) & $\begin{array}{l}-0.0124 * * \\
(-4.6643) \\
\end{array}$ & - & - & $\begin{array}{l}-0.0045^{*} \\
(-2.4775) \\
\end{array}$ & $\begin{array}{l}-0.0056^{*} \\
(-2.4660) \\
\end{array}$ & - & - \\
\hline Dummy free voter union (FVU) & - & $\begin{array}{l}-0.6658 * * \\
(-6.5112) \\
\end{array}$ & - & $\begin{array}{l}-0.5210 * * \\
(-6.1659) \\
\end{array}$ & 2 & $\begin{array}{l}0.1469 * \\
(2.3723)\end{array}$ & - \\
\hline $\begin{array}{l}\text { Ratio eligible voters/population } \\
\text { (Ratio EV/POP) }\end{array}$ & - & - & $\begin{array}{c}-0.0631 * * \\
(-8.0803)\end{array}$ & $\begin{array}{l}-0.6020 * * \\
(-6.4779) \\
\end{array}$ & - & - & $\begin{array}{l}-0.0608 * * \\
(-5.3781) \\
\end{array}$ \\
\hline $\mathrm{IM} * \mathrm{VT}$ & - & - & - & - & $\begin{array}{l}-0.0079 * \\
(-2.0309)\end{array}$ & - & - \\
\hline $\mathrm{IM} * \mathrm{FVU}$ & - & - & - & - & - & $\begin{array}{c}-1.2045 * * \\
(-5.7661) \\
\end{array}$ & - \\
\hline IM * Ratio EV/POP & - & - & - & - & - & (2) & $\begin{array}{c}0.0078 \\
(0.8322) \\
\end{array}$ \\
\hline Sigma-squared & $\begin{array}{r}0.2976 * * \\
(6.5733) \\
\end{array}$ & $\begin{array}{c}0.2689 * * \\
(6.5343) \\
\end{array}$ & $\begin{array}{c}0.2113 * * \\
(8.2073) \\
\end{array}$ & $\begin{array}{l}0.1976 * * \\
(6.8306)\end{array}$ & $\begin{array}{c}0.2499 * * \\
(6.5530) \\
\end{array}$ & $\begin{array}{l}0.2693 * * \\
(6.1351)\end{array}$ & $\begin{array}{c}0.1984 * * \\
(7.7788)\end{array}$ \\
\hline Gamma & $\begin{array}{c}0.9559 * * \\
(140.2274)\end{array}$ & $\begin{array}{c}0.9518 * * \\
(139.0069)\end{array}$ & $\begin{array}{c}0.9392 * * \\
(131.9161)\end{array}$ & $\begin{array}{l}0.9334 * * \\
(96.7381)\end{array}$ & $\begin{array}{c}0.9470 * * \\
(119.0643)\end{array}$ & $\begin{array}{c}0.9517 * * \\
(116.1515)\end{array}$ & $\begin{array}{c}0.9349 * * \\
(103.7188)\end{array}$ \\
\hline log-likelihood & 1393.22 & 1394.94 & 1399.64 & 1403.48 & 1391.88 & 1397.87 & 1399.75 \\
\hline
\end{tabular}

Note: $\mathrm{N}=2961$. Dependent variable: net current primary expenditures. $* *(*)$ denotes significance at the $5 \%(10 \%)$ level. Coefficients of the output indicators (and their quadratic and cross product terms) as well as the constant terms of the frontier and the inefficiency model are not reported for space reasons (see Appendix).

Note also that the estimation accounts for both technical change in the stochastic cost frontier and time-varying inefficiency effects. 
Turning now to the central voter involvement variables, table 3 shows that all three indicators of voter involvement add significantly to the explanatory power of the model - both independently (cfr. columns (1) through (3)) and jointly (cfr. column (4)). Hence, a first conclusion clearly is that voter involvement matters for local government (in)efficiency. A closer look reveals, moreover, that all three measures of voter involvement have a positive impact on technical efficiency. This provides support for hypothesis 1 rather than hypothesis 2. Interestingly, the size of the coefficient estimates indicates that a one standard deviation change in voter involvement has the largest effect on efficiency in the case of free voter unions and the smallest effect in case of voter turnout. This relative size of the effects makes intuitive sense. Indeed, establishing a free voter union is a very active way of involvement compared to the simple act of voting, which is often seen as the easiest and least costly (both in terms of money, time and other resources) way of participating in politics (see Milbrath, 1965; Verba and Nie, 1972). As such, it can be expected to have less far-reaching consequences in the conduct of political decision-making. ${ }^{12}$

Finally, columns (5) to (7) provide significant support for hypothesis 3. That is, the interactions between the dummy variable for fiscally autonomous (i.e. 'independent') municipalities and voter turnout (IM*VT) as well as its interaction with the presence of free voter unions (IM*FVU) show highly significant negative coefficients. The coefficient of the third interaction variable (IM*RatioEV/POP) is unexpectedly positive but remains insignificant. These findings strongly suggest that in municipalities with a higher degree of fiscal autonomy, the positive effect of voter involvement on municipal (technical) efficiency is more powerful. This is most strongly the case in column (6). There we actually observe that the positive effect of free voter unions on municipal efficiency is driven by those municipalities that are fiscally autonomous. In municipalities that are strongly dependent on external funds, the effect of voter involvement is positive (and statistically significantly too). One explanation for this result, as suggested above, is that an active citizenry is likely to put more weight on the careful (i.e. cost-efficient) use of public money when these public funds originate from own revenue sources rather than external transfers.

12 Two other reasons might explain the stronger impact of free voter unions. First, they can be interpreted as a highly independent political actor in political negotiations and monitoring activities (which, given the positive effect on efficiency, does not appear to work as a narrowly defined interest group with very specific efficiency-deterring demands). Second, the presence of free voter unions might intensify political competition since it implies a non-ideological player entering the political stage. As also discussed above, political monopolies are prone to administrative slack and inefficiencies in public service production. Free voter unions can be seen as undermining such political monopolies. 
Returning to the social capital literature referred to at the onset of this work, our findings provide some empirical backing for the assumption in this body of research that citizen participation is a force for improved government performance (e.g. Putnam, 1993). However, and crucially, we also indicate an important caveat to this. In fact, we show that high levels of voter involvement do not necessarily and automatically lead to such positive results (as Putnam, 1993, and followers appear to believe). In fact, our analysis indicates that such a result requires strict adhesion to the fiscal equivalence theorem; namely that the fiscal burden of public policies is carried directly by the municipal population (rather than being financed through external funds). When this is not the case, the positive effect of voter involvement is significantly weakened, and may even turn into a negative effect (due to the efficiencyreducing effect of special interest group politics; cfr. Mueller and Murrell, 1986).

\section{Conclusions}

In this paper we investigate the relation between voter involvement and local jurisdictions' cost efficiency. The recent social capital literature has repeatedly argued that higher social and political involvement within the population is beneficial for the performance of the public sector. From a theoretical point of view, however, it is not a priori clear whether higher voter involvement necessarily results in a higher or lower performance of (local) governments. A more active citizenry is likely to increase pressure on civil servants. While this might lead them to become more efficient, this is by no means assured. One reason is that higher participation of citizens in the political process can lead to a vague message reaching politicians (as preferences in the population are likely to be heterogeneous). Moreover, voters may only care about the careful use of public money when it originates from own (tax) revenue sources rather than external transfers. As a consequence, high voter involvement is more likely to result in better (or more efficient) performance in municipalities with a high rather than low - degree of fiscal autonomy.

Using this theoretical framework, our empirical analysis - using a broad panel of 987 German municipalities for the years 1998, 2002 and 2004 - illustrates that higher voter involvement can on the whole be associated with higher rather than lower levels of (technical) efficiency. This conclusion is in line with previous findings by Borge et al. (2007) for Norwegian municipalities. Compared to their results, however, our analysis allows for two more detailed conclusions. First, we find that this positive relation between voter involvement and government efficiency is supported also for measures of involvement other than (simple) 
voter turnout. In fact, we show that it holds for all three measures of voter involvement employed in the current analysis: (1) voter turnout, (2) the presence of free voter unions in the local council, and (3) the ratio of eligible voters to total population. Interestingly, the effect is found to be weakest for voter turnout. Second, and crucially, our results reveal that this positive relation between voter involvement and government efficiency is not automatic. Rather, it is stronger when the degree of fiscal autonomy of the municipality is higher. As a consequence, stimulating civic engagement in politics is especially desirable when the institutional setting is such that the fiscal burden of public policies falls on those voting for these policies (i.e. a high degree of fiscal equivalence; cfr. Olson, 1969).

These findings provide some food for thought in terms of their policy implications. At first sight, they suggest that one should try to encourage citizens to be more active in the political process (e.g. via casting a ballot). Indeed, higher levels of voter involvement on the whole increase government performance. This is, however, not an easy route to take. Voter involvement in Baden-Württemberg (as elsewhere) is de facto decreasing. For example, in the period considered here voter turnout in local council elections fell from approximately $67 \%$ in 1994 to $52 \%$ in 2004 . A more detailed reading of our results, however, shows that this is not the only way to increase local government performance. Indeed, an alternative route is to increase the degree of local governments' fiscal (or revenue) autonomy. Our results indeed suggest that the effect of voter involvement is stronger in fiscally more autonomous (and therefore less dependent on external transfers) municipalities. Even though actual involvement declines (see above), higher budgetary slack can then still be avoided by making municipalities depend to a stronger degree on own funding. In such a setting, an active citizenry will put more weight on the careful use of public money. 


\section{References}

Aigner, D.J., C.A.K. Lovell, and P. Schmidt (1977). Formulation and estimation of stochastic frontier production function models. Journal of Econometrics, 6: 21-37.

Alt, J.E., and D.D. Lassen (2006). Fiscal transparency, political parties and debt in OECD countries, European Economic Review, 50(6), 1403-1439.

Ashworth, J., B. Geys. B. Heyndels, and F. Wille (2007). Political Competition and Local Government Performance: Evidence from Flemish Municipalities, Vrije Universiteit Brussel, mimeo.

Balaguer-Coll, M.T., D. Prior, and E. Tortosa-Ausina (2007). On the determinants of local government performance: A two-stage nonparametric approach. European Economic Review, 51(2): 425-451.

Battese G.E., and T.J. Coelli (1995). A Model for Technical Efficiency Effects in a Stochastic Frontier Production Function with Panel Data. Empirical Economics, 20: 325-332.

Bjørnskov, C. (2003). Corruption and social capital. Aarhus School of Business Working Paper, $n^{\circ}$ 03-13.

Boix, C., \& Posner, D.N. (1998). Social capital: Explaining its origins and effects on government performance. British Journal of Political Science, 28, 686-693.

Borge, L.-E., T. Falch, and P. Tovmo (2007). Public Sector Efficiency: The Roles of Political and Budgetary Institutions, Fiscal Capacity and Democratic Participation. NTNU Department of Economics Working Paper, No. 2007/01.

Brady, H.E., S. Verba and K.L. Schlozman (1995). Beyond SES: A Resource Model of Political Participation. American Political Science Review 89(2): 271-294.

Casey, T. (2004). Social capital and regional economies in Britain. Political Studies, 52, 96117.

Chan, K.S. and S. Mestelman (1988). Institutions, Efficiency and the Strategic Behaviour of Sponsors and Bureaucracy, Journal of Public Economics, 37: 91-102.

Christensen, L.R., D.W. Jorgenson, and L.J. Lawrence (1973). Transcendental logarithmic production frontiers. Review of Economics and Statistics, 55(1): 28-45.

Coelli T.J. (1996). A Guide to FRONTIER version 4.1: A Computer Program for Stochastic Frontier Production and Cost Function Estimation. CEPA Working papers, No. 7/96.

Coffé, H. and Geys, B. (2005). Institutional Performance and Social Capital: An Application to the Local Government Level, Journal of Urban Affairs, 27(5), 485-501.

Coffé, H. and Geys, B. (2007a). Towards an Empirical Characterization of Bridging and Bonding Social Capital, Nonprofit and Voluntary Sector Quarterly, 36(1): 121-39.

Coffé, H. and Geys, B. (2007b). Measuring the Bridging Potential of Voluntary Associations: The Importance of Association Size, Sociology, forthcoming.

Cusack, T.R. (1999). Social capital, institutional structures and democratic performance: A comparative study of German local governments. European Journal of Political Research, $35,1-34$.

De Borger, B., K. Kerstens, W. Moesen, and J. Vanneste (1994). Explaining differences in productive efficiency: An application to Belgian municipalities. Public Choice, 80: 339358. 
De Borger, B., and K. Kerstens (1996). Cost efficiency of Belgian local governments: A comparative analysis of FDH, DEA and econometric approaches. Regional Science and Urban Economics, 26: 145-170.

De Borger, B., and K. Kerstens (2000). What is known about municipal efficiency? The Belgian case and beyond. In: Public Provision and Performance: Contributions from Efficiency and Productivity Measurement, ed. J. Blank, 299-330. Elsevier: Amsterdam.

Geys, B. (2006). Looking across borders: A test of spatial policy interdependence using local government efficiency ratings. Journal of Urban Economics, 60 (3): 443-462.

Geys, B. (2008). How to make Head or Tail of Bridging and Bonding?: Addressing the Methodological Ambiguity, British Journal of Sociology, forthcoming.

Geys B., and W. Moesen (2007a). Measuring Local Government Technical Efficiency in Flemish Municipalities: An Application and Comparison of FDH, DEA and Econometric Approaches. WZB Berlin, mimeo.

Geys B., and W. Moesen (2007b). Sources of Local Government Technical Efficiency: Evidence from Flemish Municipalities. WZB Berlin, mimeo.

Heyndels, B. (2001). Asymmetries in the flypaper effect: empirical evidence for the Flemish municipalities, Applied Economics, 33, 1329-1334.

Heyndels, B. and C. Smolders (1994). An empirical test of the fiscal illusion hypothesis, Public Choice, 80(3-4), 325-338.

Hines, J.R., R.H. Thaler (1995). Anomalies. The Flypaper Effect. Journal of Economic Perspectives 9(4): 217-226.

Kalseth, J., and J. Rattsø (1998). Political control of administrative spending: The case of local governments in Norway. Economics and Politics, 10: 63-83.

Levitt, M., and M. Joyce (1987). The growth and efficiency of public spending, Cambridge University Press, Cambridge.

Lovell, C.A.K. (1993). Production frontiers and productive efficiency. In: The Measurement of Productive Efficiency: Techniques and Applications, eds. H. Fried, C.A.K. Lovell and S. Schmidt, 3-67. Oxford: Oxford University Press.

Meeusen, W., and J. van den Broeck (1977). Efficiency estimation from Cobb-Douglas production functions with composed error. International Economic Review, 18 (2): 435444.

Migué, J. and G. Bélanger (1974). Toward a General Theory of Manegerial Discretion, Public Choice, 17: 27-43.

Ministry of Finance of Baden-Württemberg (2006). Die Gemeinden und ihre Finanzen, Stuttgart.

Milbrath, L. (1965), Political Participation: How and Why do People get Involved in Politics? Rand McNally College Publishing: Chicago.

Mueller, D.C. and P. Murrell (1986). Interest Groups and the Size of Government, Public Choice, 48, 125-145.

Moene, K.O. (1986). Types of Bureaucratic Interaction, Journal of Public Economics, 29: 333-345.

Niskanen, W.A. (1975). Bureaucrats and Politicians, Journal of Law and Economics, 18: 617643. 
Olson, M. (1965). The Logic of Collective Action: Public Goods and the Theory of Groups. Cambridge: Cambridge University Press.

Olson, M. (1969). The Principle of 'Fiscal Equivalence': The Division of Responsibilities among Different Levels of Government, American Economic Review, 59: 479-487.

Olson, M. (1982). The rise and decline of nations. New Haven: Yale University Press.

Paxton, P. (2002). Social Capital and Democracy: An Interdependent Relationship, American Sociological Review 67: 254-77.

Putnam, R. (1993). Making Democracy Work. Civic Traditions in Modern Italy, Princeton: Princeton University Press.

Schattschneider, E.E. (1960). The Semisovereign People: A Realist's View of Democracy in America. Fort Worth: Harcourt, Brace.

Scheufele, D.A., M.C. Nisbet, D. Brossard, and E.C. Nisbet (2004). Social structure and citizenship: Examining the impacts of social setting, network heterogeneity, and informational variables on political participation. Political Communication, 21(3), 315338.

Serra, R. (1999). 'Putnam in India': Is social capital a meaningful and measurable concept at Indian state level? IDS Working Paper 92. University of Sussex.

Shi, M., and J. Svensson (2006). Political budget cycles: Do they differ across countries and why? Journal of Public Economics, 90 (8-9): 1367-1389.

Squire, P., R.E. Wolfinger, and D.P. Glass (1987). Residential Mobility and Voter Turnout. American Political Science Review 81: 45-65.

Stevens P.A. (2004). Accounting for Background Variables in Stochastic Frontier Analysis. NIESR Discussion Paper, No. 239.

Stevens P.A. (2005). Assessing the Performance of Local Government. National Institute Economic Review, No. 193.

Stolle, D., and T.R. Rochon (1998). Are All Associations Alike? Member Diversity, Associational Type, and the Creation of Social Capital, American Behavioral Scientist 42(1): 47-65.

Toka, G. (2008). Citizen Information, Election Outcomes and Good Governance, Electoral Studies, 27: 31-44.

Vanden Eeckhaut, P., H. Tulkens, and M. Jamar (1993). Cost efficiency in Belgian municipalities. In H. Fried, C.A.K. Lovell, and S. Schmidt (Eds.), The measurement of productive efficiency: Techniques and applications (pp. 300-334). Oxford: Oxford University Press.

Verba, S., and N.H. Nie (1972). Participation in America. Political democracy and social equality, Harper and Row: New York.

Worthington, A.C. (2000). Cost efficiency in Australian local government: A comparative analysis of mathematical programming and econometric approaches. Financial Accountability and Management, 16 (3): 201-223. 


\section{Appendix}

Table A1: Complete results of the multi-output frontier estimation

\begin{tabular}{|c|c|c|c|c|c|c|c|}
\hline Variable & $(1)$ & $(2)$ & (3) & $(4)$ & (5) & $(6)$ & $(7)$ \\
\hline \multicolumn{8}{|c|}{ Stochastic frontier } \\
\hline Constant & $\begin{array}{l}13.0831 * * \\
(17.3273)\end{array}$ & $\begin{array}{l}13.0077 * * \\
(17.3178)\end{array}$ & $\begin{array}{l}13.1690 * * \\
(17.5426)\end{array}$ & $\begin{array}{l}13.2472 * * \\
(17.6644)\end{array}$ & $\begin{array}{l}12.9712 * * \\
(17.0529)\end{array}$ & $\begin{array}{l}12.9762 * * \\
(17.2719)\end{array}$ & $\begin{array}{l}12.9268^{* *} \\
(17.0307)\end{array}$ \\
\hline $\begin{array}{l}\text { A: Students in public } \\
\text { school }\end{array}$ & $\begin{array}{c}0.1297 \\
(1.4091)\end{array}$ & $\begin{array}{c}0.1261 \\
(1.3491)\end{array}$ & $\begin{array}{c}0.1447 \\
(1.5744)\end{array}$ & $\begin{array}{l}0.1556^{*} \\
(1.6834)\end{array}$ & $\begin{array}{c}0.1272 \\
(1.3744)\end{array}$ & $\begin{array}{c}0.1285 \\
(1.3627)\end{array}$ & $\begin{array}{c}0.1469 \\
(1.6144)\end{array}$ \\
\hline B: Kindergarten places & $\begin{array}{l}0.5836^{*} \\
(2.1895)\end{array}$ & $\begin{array}{l}0.6137^{*} \\
(2.3180)\end{array}$ & $\begin{array}{l}0.6094 * \\
(2.2803)\end{array}$ & $\begin{array}{l}0.5807^{*} \\
(2.2498)\end{array}$ & $\begin{array}{l}0.5630^{*} \\
(2.1181)\end{array}$ & $\begin{array}{l}0.5836^{*} \\
(2.2088)\end{array}$ & $\begin{array}{l}0.5527^{*} \\
(2.1213)\end{array}$ \\
\hline C: Recovery area & $\begin{array}{c}0.4265^{* *} \\
(3.7748) \\
\end{array}$ & $\begin{array}{c}0.4189 * * \\
(3.7472)\end{array}$ & $\begin{array}{c}0.4110 * * \\
(3.6441)\end{array}$ & $\begin{array}{c}0.4097 * * \\
(3.6851)\end{array}$ & $\begin{array}{c}0.4358 * * \\
(3.9515) \\
\end{array}$ & $\begin{array}{c}0.4241 * * \\
(3.7747)\end{array}$ & $\begin{array}{c}0.4275^{* *} \\
(3.9533)\end{array}$ \\
\hline D: Total population & $\begin{array}{l}-2.1708^{* *} \\
(-3.8502) \\
\end{array}$ & $\begin{array}{l}-2.1479^{* *} \\
(-3.8262) \\
\end{array}$ & $\begin{array}{l}-2.2452 * * \\
(-3.9976) \\
\end{array}$ & $\begin{array}{l}-2.3001^{* *} \\
(-4.0987) \\
\end{array}$ & $\begin{array}{l}-2.0837 * * \\
(-3.6670) \\
\end{array}$ & $\begin{array}{l}-2.1281 * * \\
(-3.7923) \\
\end{array}$ & $\begin{array}{c}-1.9993^{* *} \\
(-3.4750) \\
\end{array}$ \\
\hline $\begin{array}{l}\text { E: Population older than } \\
65\end{array}$ & $\begin{array}{c}0.4689 \\
(1.0869) \\
\end{array}$ & $\begin{array}{c}0.4569 \\
(1.0722) \\
\end{array}$ & $\begin{array}{c}0.4981 \\
(1.1627) \\
\end{array}$ & $\begin{array}{c}0.5565 \\
(1.3154) \\
\end{array}$ & $\begin{array}{c}0.4123 \\
(0.9731) \\
\end{array}$ & $\begin{array}{c}0.4533 \\
(1.0619) \\
\end{array}$ & $\begin{array}{c}0.2912 \\
(0.6793) \\
\end{array}$ \\
\hline $\begin{array}{l}\text { F: Number of social } \\
\text { insured employees }\end{array}$ & $\begin{array}{l}0.7946 * * \\
(5.1448) \\
\end{array}$ & $\begin{array}{l}0.7794 * * \\
(5.0693) \\
\end{array}$ & $\begin{array}{l}0.8180^{* *} \\
(5.3491) \\
\end{array}$ & $\begin{array}{l}0.8230^{* *} \\
(5.3313) \\
\end{array}$ & $\begin{array}{l}0.7812 * * \\
(5.1547) \\
\end{array}$ & $\begin{array}{l}0.7842 * * \\
(5.0996) \\
\end{array}$ & $\begin{array}{l}0.8121^{* *} \\
(5.4090) \\
\end{array}$ \\
\hline $\mathrm{A}^{2}$ & $\begin{array}{l}-0.0053 \\
(-1.3451)\end{array}$ & $\begin{array}{l}-0.0055 \\
(-1.4093)\end{array}$ & $\begin{array}{c}-0.0045 \\
(-1.1445)\end{array}$ & $\begin{array}{c}-0.0042 \\
(-1.0776)\end{array}$ & $\begin{array}{c}-0.0051 \\
(-1.3191)\end{array}$ & $\begin{array}{c}-0.0055 \\
(-1.3951)\end{array}$ & $\begin{array}{c}-0.0042 \\
(-1.1150)\end{array}$ \\
\hline $\mathrm{B}^{2}$ & $\begin{array}{l}0.0243 * * \\
(2.5927) \\
\end{array}$ & $\begin{array}{l}0.0256^{*} \\
(2.4510) \\
\end{array}$ & $\begin{array}{l}0.0250 * * \\
(2.6013)\end{array}$ & $\begin{array}{c}0.0250^{* *} \\
(2.7472) \\
\end{array}$ & $\begin{array}{l}0.0239^{*} \\
(2.4644)\end{array}$ & $\begin{array}{l}0.0242 * \\
(2.4970) \\
\end{array}$ & $\begin{array}{l}0.0246^{*} \\
(2.5470) \\
\end{array}$ \\
\hline $\mathrm{C}^{2}$ & $\begin{array}{c}0.0022 \\
(0.5882)\end{array}$ & $\begin{array}{c}0.0026 \\
(0.7302) \\
\end{array}$ & $\begin{array}{c}0.0027 \\
(0.7046) \\
\end{array}$ & $\begin{array}{c}0.0029 \\
(0.7739) \\
\end{array}$ & $\begin{array}{c}0.0021 \\
(0.6026)\end{array}$ & $\begin{array}{c}0.0025 \\
(0.7076)\end{array}$ & $\begin{array}{c}0.0024 \\
(0.6746)\end{array}$ \\
\hline $\mathrm{D}^{2}$ & $\begin{array}{l}0.3614 * * \\
(3.0547)\end{array}$ & $\begin{array}{l}0.3618^{* *} \\
(3.0646)\end{array}$ & $\begin{array}{c}0.3764 * * \\
(3.1935)\end{array}$ & $\begin{array}{c}0.3879 * * \\
(3.2825)\end{array}$ & $\begin{array}{c}0.3441^{* *} \\
(2.9090)\end{array}$ & $\begin{array}{c}0.3569^{* *} \\
(3.0275)\end{array}$ & $\begin{array}{l}0.3222 * * \\
(2.6795)\end{array}$ \\
\hline $\mathrm{E}^{2}$ & $\begin{array}{c}-0.0439 \\
(-0.5818) \\
\end{array}$ & $\begin{array}{c}-0.0354 \\
(-0.4743) \\
\end{array}$ & $\begin{array}{c}-0.0406 \\
(-0.5415) \\
\end{array}$ & $\begin{array}{c}-0.0280 \\
(-0.3721) \\
\end{array}$ & $\begin{array}{c}-0.0463 \\
(-0.6374) \\
\end{array}$ & $\begin{array}{c}-0.0373 \\
(-0.5017) \\
\end{array}$ & $\begin{array}{c}-0.0666 \\
(-0.9188) \\
\end{array}$ \\
\hline $\mathrm{F}^{2}$ & $\begin{array}{l}0.0480^{* *} \\
(5.2278)\end{array}$ & $\begin{array}{l}0.0485 * * \\
(5.2535)\end{array}$ & $\begin{array}{c}0.0485 * * \\
(5.2462)\end{array}$ & $\begin{array}{c}0.0472 * * \\
(5.2196)\end{array}$ & $\begin{array}{c}0.0481^{* *} \\
(5.3775)\end{array}$ & $\begin{array}{c}0.0494 * * \\
(5.3744)\end{array}$ & $\begin{array}{l}0.0490^{* *} \\
(5.4751)\end{array}$ \\
\hline $\mathrm{F} * \mathrm{E}$ & $\begin{array}{c}0.0520 \\
(1.3939) \\
\end{array}$ & $\begin{array}{c}0.0486 \\
(1.3297) \\
\end{array}$ & $\begin{array}{c}0.0633^{*} \\
(1.7040) \\
\end{array}$ & $\begin{array}{c}0.0651^{*} \\
(1.7959) \\
\end{array}$ & $\begin{array}{c}0.0478 \\
(1.3037) \\
\end{array}$ & $\begin{array}{c}0.0475 \\
(1.2870) \\
\end{array}$ & $\begin{array}{c}0.0588 \\
(1.6052) \\
\end{array}$ \\
\hline $\mathrm{F} * \mathrm{D}$ & $\begin{array}{c}-0.3014 * * \\
(-5.2010)\end{array}$ & $\begin{array}{c}-0.2977 * * \\
(-5.1877)\end{array}$ & $\begin{array}{c}-0.3102 * * \\
(-5.4021)\end{array}$ & $\begin{array}{c}-0.3109 * * \\
(-5.3834)\end{array}$ & $\begin{array}{c}-0.2966^{* *} \\
(-5.2233)\end{array}$ & $\begin{array}{c}-0.2977 * * \\
(-5.1659)\end{array}$ & $\begin{array}{c}-0.3061 * * \\
(-5.4184)\end{array}$ \\
\hline $\mathrm{F} * \mathrm{C}$ & $\begin{array}{c}0.171^{*} \\
(1.9666) \\
\end{array}$ & $\begin{array}{l}0.0161^{*} \\
(1.8674) \\
\end{array}$ & $\begin{array}{c}0.0156^{*} \\
(1.8026) \\
\end{array}$ & $\begin{array}{c}0.0157^{*} \\
(1.8185) \\
\end{array}$ & $\begin{array}{l}0.0170^{*} \\
(2.0280) \\
\end{array}$ & $\begin{array}{c}0.0168^{*} \\
(1.9568)\end{array}$ & $\begin{array}{c}0.0163^{*} \\
(1.9388) \\
\end{array}$ \\
\hline $\mathrm{F} * \mathrm{~B}$ & $\begin{array}{c}0.1326^{* *} \\
(4.2382) \\
\end{array}$ & $\begin{array}{c}0.1346^{* *} \\
(4.2850) \\
\end{array}$ & $\begin{array}{c}0.1298^{* *} \\
(4.1563) \\
\end{array}$ & $\begin{array}{c}0.1301^{* *} \\
(4.1632) \\
\end{array}$ & $\begin{array}{l}0.1332 * * \\
(4.3391) \\
\end{array}$ & $\begin{array}{c}0.1321^{* *} \\
(4.1842) \\
\end{array}$ & $\begin{array}{c}0.1283^{* *} \\
(4.1667) \\
\end{array}$ \\
\hline $\mathrm{F} * \mathrm{~A}$ & $\begin{array}{c}0.0105 \\
(1.1284) \\
\end{array}$ & $\begin{array}{c}0.0098 \\
(1.0370) \\
\end{array}$ & $\begin{array}{c}0.0089 \\
(0.9661) \\
\end{array}$ & $\begin{array}{c}0.0096 \\
(1.0206) \\
\end{array}$ & $\begin{array}{c}0.0098 \\
(1.0839) \\
\end{array}$ & $\begin{array}{c}0.0099 \\
(1.0365) \\
\end{array}$ & $\begin{array}{c}0.0091 \\
(1.0098) \\
\end{array}$ \\
\hline$E * D$ & $\begin{array}{c}0.0452 \\
(0.2438) \\
\end{array}$ & $\begin{array}{c}0.0388 \\
(0.2109) \\
\end{array}$ & $\begin{array}{c}0.0271 \\
(0.1471) \\
\end{array}$ & $\begin{array}{c}0.0018 \\
(0.0098) \\
\end{array}$ & $\begin{array}{c}0.0649 \\
(0.3597) \\
\end{array}$ & $\begin{array}{c}0.0437 \\
(0.2381) \\
\end{array}$ & $\begin{array}{c}0.1084 \\
(0.5960) \\
\end{array}$ \\
\hline $\mathrm{E} * \mathrm{C}$ & $\begin{array}{l}0.0921 * * \\
(3.1953)\end{array}$ & $\begin{array}{l}0.0890 * * \\
(3.1064)\end{array}$ & $\begin{array}{c}0.0893 * * \\
(3.0789) \\
\end{array}$ & $\begin{array}{c}0.0863 * * \\
(3.0808)\end{array}$ & $\begin{array}{l}0.0941^{* *} \\
(3.3635)\end{array}$ & $\begin{array}{c}0.0897^{* *} \\
(3.1277)\end{array}$ & $\begin{array}{c}0.0925^{* *} \\
(3.3370)\end{array}$ \\
\hline $\mathrm{E} * \mathrm{~B}$ & $\begin{array}{l}-0.2060^{*} \\
(-2.3771)\end{array}$ & $\begin{array}{l}-0.2069^{*} \\
(-2.3975)\end{array}$ & $\begin{array}{l}-0.1940^{*} \\
(-2.2362)\end{array}$ & $\begin{array}{c}-0.1983^{*} \\
(-2.2633)\end{array}$ & $\begin{array}{l}-0.2165^{*} \\
(-2.5143)\end{array}$ & $\begin{array}{l}-0.2082^{*} \\
(-2.4103)\end{array}$ & $\begin{array}{l}-0.2199^{*} \\
(-2.5469)\end{array}$ \\
\hline $\mathrm{E} * \mathrm{~A}$ & $\begin{array}{c}-0.0088 \\
(-0.3407) \\
\end{array}$ & $\begin{array}{c}-0.0100 \\
(-0.3837) \\
\end{array}$ & $\begin{array}{c}-0.0133 \\
(-0.5206) \\
\end{array}$ & $\begin{array}{c}-0.0093 \\
(-0.3576)\end{array}$ & $\begin{array}{c}-0.0101 \\
(-0.3885) \\
\end{array}$ & $\begin{array}{c}-0.0097 \\
(-0.3651) \\
\end{array}$ & $\begin{array}{c}-0.0128 \\
(-0.4970) \\
\end{array}$ \\
\hline $\mathrm{D} * \mathrm{C}$ & $\begin{array}{c}-0.1310^{* *} \\
(-3.0948)\end{array}$ & $\begin{array}{c}-0.1279 * * \\
(-3.0644)\end{array}$ & $\begin{array}{c}-0.1265^{* *} \\
(-2.9988) \\
\end{array}$ & $\begin{array}{c}-0.1243^{* *} \\
(-3.0309) \\
\end{array}$ & $\begin{array}{c}-0.1345^{* *} \\
(-3.2680) \\
\end{array}$ & $\begin{array}{c}-0.1297^{* *} \\
(-3.0891) \\
\end{array}$ & $\begin{array}{c}-0.1322 * * \\
(-3.2643)\end{array}$ \\
\hline $\mathrm{D} * \mathrm{~B}$ & $\begin{array}{c}-0.0538 \\
(-0.5971) \\
\end{array}$ & $\begin{array}{c}-0.0600 \\
(-0.6694) \\
\end{array}$ & $\begin{array}{c}-0.0635 \\
(-0.7037) \\
\end{array}$ & $\begin{array}{c}-0.0566 \\
(-0.6304) \\
\end{array}$ & $\begin{array}{c}-0.0433 \\
(-0.4764) \\
\end{array}$ & $\begin{array}{c}-0.0517 \\
(-0.5761) \\
\end{array}$ & $\begin{array}{c}-0.0359 \\
(-0.3971) \\
\end{array}$ \\
\hline $\mathrm{D} * \mathrm{~A}$ & $\begin{array}{c}-0.0441 \\
(-1.2612) \\
\end{array}$ & $\begin{array}{c}-0.0417 \\
(-1.1776) \\
\end{array}$ & $\begin{array}{c}-0.0421 \\
(-1.2199) \\
\end{array}$ & $\begin{array}{c}-0.0461 \\
(-1.3327) \\
\end{array}$ & $\begin{array}{c}-0.0418 \\
(-1.1822) \\
\end{array}$ & $\begin{array}{c}-0.0426 \\
(-1.1886) \\
\end{array}$ & $\begin{array}{c}-0.0422 \\
(-1.2166) \\
\end{array}$ \\
\hline $\mathrm{C} * \mathrm{~B}$ & $\begin{array}{c}-0.0202 \\
(-0.9299) \\
\end{array}$ & $\begin{array}{c}-0.0197 \\
(-0.9095) \\
\end{array}$ & $\begin{array}{c}-0.0205 \\
(-0.9382) \\
\end{array}$ & $\begin{array}{c}-0.0201 \\
(-0.9309) \\
\end{array}$ & $\begin{array}{c}-0.0189 \\
(-0.8788) \\
\end{array}$ & $\begin{array}{c}-0.0198 \\
(-0.9018) \\
\end{array}$ & $\begin{array}{c}-0.0184 \\
(-0.8572) \\
\end{array}$ \\
\hline $\mathrm{C} * \mathrm{~A}$ & $\begin{array}{c}0.0092 \\
(1.5046) \\
\end{array}$ & $\begin{array}{c}0.0088 \\
(1.4362) \\
\end{array}$ & $\begin{array}{c}0.0093 \\
(1.5172) \\
\end{array}$ & $\begin{array}{c}0.0087 \\
(1.4835) \\
\end{array}$ & $\begin{array}{c}0.0094 \\
(1.6267) \\
\end{array}$ & $\begin{array}{c}0.0092 \\
(1.4981) \\
\end{array}$ & $\begin{array}{c}0.0090 \\
(1.5559) \\
\end{array}$ \\
\hline $\mathrm{B} * \mathrm{~A}$ & $\begin{array}{l}0.0400 * \\
(1.6878)\end{array}$ & $\begin{array}{c}0.0394 \\
(1.6348)\end{array}$ & $\begin{array}{c}0.0388^{*} \\
(1.6513)\end{array}$ & $\begin{array}{c}0.0376^{*} \\
(1.6641)\end{array}$ & $\begin{array}{c}0.0383 \\
(1.6187)\end{array}$ & $\begin{array}{c}0.0397 \\
(1.6374)\end{array}$ & $\begin{array}{c}0.0377 \\
(1.6169)\end{array}$ \\
\hline Year1 & $\begin{array}{c}0.0339 * * \\
(8.3878) \\
\end{array}$ & $\begin{array}{c}0.0344 * * \\
(8.7181)\end{array}$ & $\begin{array}{c}0.0332^{* *} \\
(7.4540)\end{array}$ & $\begin{array}{c}0.0324 * * \\
(7.4079)\end{array}$ & $\begin{array}{c}0.0352 * * \\
(7.5768)\end{array}$ & $\begin{array}{c}0.0357 * * \\
(8.7792) \\
\end{array}$ & $\begin{array}{c}0.0328^{* *} \\
(6.7549) \\
\end{array}$ \\
\hline
\end{tabular}




\begin{tabular}{|c|c|c|c|c|c|c|c|}
\hline \multicolumn{8}{|c|}{ Table A1 (continued): Complete results of the multi-output frontier estimation } \\
\hline \multicolumn{8}{|c|}{ Inefficiency model } \\
\hline Constant & $\begin{array}{l}-1.6025^{* *} \\
(-4.1933)\end{array}$ & $\begin{array}{l}-1.1508 * * \\
(-3.3095)\end{array}$ & $\begin{array}{l}3.1445^{* *} \\
(9.4701)\end{array}$ & $\begin{array}{c}4.0774 * * \\
(7.5925)\end{array}$ & $\begin{array}{l}-1.6503 * * \\
(-3.7218)\end{array}$ & $\begin{array}{l}-1.9804 * * \\
(-3.8106)\end{array}$ & $\begin{array}{l}2.9785^{* *} \\
(5.3281)\end{array}$ \\
\hline Unemployment rate & $\begin{array}{l}-0.0247 * * \\
(-3.5136)\end{array}$ & $\begin{array}{l}-0.0514 * * \\
(-6.7206)\end{array}$ & $\begin{array}{l}-0.0439 * * \\
(-5.7417)\end{array}$ & $\begin{array}{l}-0.0365^{* *} \\
(-4.5828)\end{array}$ & $\begin{array}{l}-0.0235^{* *} \\
(-2.5856)\end{array}$ & $\begin{array}{l}-0.0490 * * \\
(-6.8962)\end{array}$ & $\begin{array}{l}-0.0410 * * \\
(-4.3281)\end{array}$ \\
\hline Population density & $\begin{array}{l}-0.0555^{* *} \\
(-6.3933)\end{array}$ & $\begin{array}{l}-0.0464 * * \\
(-7.4453)\end{array}$ & $\begin{array}{l}-0.0485^{* *} \\
(-7.4488)\end{array}$ & $\begin{array}{l}-0.0409 * * \\
(-5.9351)\end{array}$ & $\begin{array}{l}-0.0529 * * \\
(-5.8337)\end{array}$ & $\begin{array}{c}-0.0468 * * \\
(-7.6972)\end{array}$ & $\begin{array}{c}-0.0447 * * \\
(-5.9409)\end{array}$ \\
\hline Herfindahl index & $\begin{array}{l}0.3453^{* *} \\
(5.0724)\end{array}$ & $\begin{array}{l}0.1254^{*} \\
(2.4019)\end{array}$ & $\begin{array}{l}0.1264 * * \\
(2.6597)\end{array}$ & $\begin{array}{c}0.0036 \\
(0.0779)\end{array}$ & $\begin{array}{l}0.3317^{* *} \\
(3.8551)\end{array}$ & $\begin{array}{l}0.1607 * * \\
(2.6988)\end{array}$ & $\begin{array}{l}0.1343^{*} \\
(2.0125)\end{array}$ \\
\hline Share of left & $\begin{array}{l}-0.0025^{*} \\
(-2.4930)\end{array}$ & $\begin{array}{l}-0.0090 * * \\
(-4.9833)\end{array}$ & $\begin{array}{l}-0.0015 \\
(-1.4163)\end{array}$ & $\begin{array}{l}-0.0058^{* *} \\
(-4.4367)\end{array}$ & $\begin{array}{l}-0.0015 \\
(-1.2759)\end{array}$ & $\begin{array}{l}-0.0090 * * \\
(-4.0450)\end{array}$ & $\begin{array}{l}-0.0005 \\
(-0.4546)\end{array}$ \\
\hline $\begin{array}{l}\text { Dummy independent } \\
\text { municipality (IM) }\end{array}$ & $\begin{array}{l}2.5062 * * \\
(6.1182)\end{array}$ & $\begin{array}{l}2.2549^{* *} \\
(6.0632)\end{array}$ & $\begin{array}{l}1.7430^{* *} \\
(7.6678)\end{array}$ & $\begin{array}{l}1.6732 * * \\
(6.4256)\end{array}$ & $\begin{array}{l}2.7270^{* *} \\
(5.3425)\end{array}$ & $\begin{array}{l}3.3852^{* *} \\
(5.9887)\end{array}$ & $\begin{array}{l}1.1467^{*} \\
(1.9620)\end{array}$ \\
\hline Voter turnout (VT) & $\begin{array}{l}-0.0124 * * \\
(-4.6643)\end{array}$ & - & - & $\begin{array}{l}-0.0045^{*} \\
(-2.4775)\end{array}$ & $\begin{array}{l}-0.0056^{*} \\
(-2.4660)\end{array}$ & (2) & - \\
\hline $\begin{array}{l}\text { Dummy free voter union } \\
\text { (FVU) }\end{array}$ & 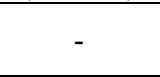 & $\begin{array}{l}-0.6658 * * \\
(-6.5112)\end{array}$ & - & $\begin{array}{c}-0.5210^{* *} \\
(-6.1659)\end{array}$ & (2) & $\begin{array}{l}0.1469^{*} \\
(2.3723)\end{array}$ & - \\
\hline $\begin{array}{l}\text { Ratio eligible voters } \\
\text { (EV) / population (POP) }\end{array}$ & - & - & $\begin{array}{c}-0.0631 * * \\
(-8.0803)\end{array}$ & $\begin{array}{l}-0.6020 * * \\
(-6.4779)\end{array}$ & - & - & $\begin{array}{c}-0.0608 * * \\
(-5.3781)\end{array}$ \\
\hline $\mathrm{IM} * \mathrm{VT}$ & - & - & - & (2) & $\begin{array}{l}-0.0079^{*} \\
(-2.0309)\end{array}$ & - & (2) \\
\hline $\mathrm{IM} * \mathrm{FVU}$ & - & - & - & - & - & $\begin{array}{c}-1.2045^{* *} \\
(-5.7661) \\
\end{array}$ & - \\
\hline $\mathrm{IM} *$ RatioEV/POP & - & - & - & - & - & 2 & $\begin{array}{c}0.0078 \\
(0.8322)\end{array}$ \\
\hline Year2 & $\begin{array}{c}-0.1326^{* *} \\
(-5.2779) \\
\end{array}$ & $\begin{array}{c}-0.0945^{* *} \\
(-5.8795) \\
\end{array}$ & $\begin{array}{c}-0.0131 \\
(-0.9589) \\
\end{array}$ & $\begin{array}{l}-0.0411^{*} \\
(-2.4968) \\
\end{array}$ & $\begin{array}{c}-0.1359^{* *} \\
(-4.5517) \\
\end{array}$ & $\begin{array}{c}-0.0949^{* *} \\
(-6.1454) \\
\end{array}$ & $\begin{array}{c}-0.0101 \\
(-0.5494) \\
\end{array}$ \\
\hline Sigma-squared & $\begin{array}{c}0.2976^{* *} \\
(6.5733) \\
\end{array}$ & $\begin{array}{c}0.2689^{* *} \\
(6.5343) \\
\end{array}$ & $\begin{array}{c}0.2113 * * \\
(8.2073) \\
\end{array}$ & $\begin{array}{c}0.1976^{* *} \\
(6.8306) \\
\end{array}$ & $\begin{array}{c}0.2499^{* *} \\
(6.5530) \\
\end{array}$ & $\begin{array}{c}0.2693 * * \\
(6.1351) \\
\end{array}$ & $\begin{array}{c}0.1984^{* *} \\
(7.7788) \\
\end{array}$ \\
\hline Gamma & $\begin{array}{c}0.9559 * * \\
(140.2274)\end{array}$ & $\begin{array}{c}0.9518^{* *} \\
(139.0069)\end{array}$ & $\begin{array}{c}0.9392 * * \\
(131.9161)\end{array}$ & $\begin{array}{l}0.9334 * * \\
(96.7381) \\
\end{array}$ & $\begin{array}{c}0.9470 * * \\
(119.0643)\end{array}$ & $\begin{array}{c}0.9517^{* *} \\
(116.1515)\end{array}$ & $\begin{array}{c}0.9349 * * \\
(103.7188) \\
\end{array}$ \\
\hline log-likelihood & 1393.22 & 1394.94 & 1399.64 & 1403.48 & 1391.88 & 1397.87 & 1399.75 \\
\hline
\end{tabular}

Note: $\mathrm{N}=2961$. Dependent variable: net current primary expenditures. The dependent as well as the output variables are in natural logs. ** (*) denotes significance at the 5\% (10\%) level. The variables "year1" and "year2" accounts for both technical change in the stochastic cost frontier and time-varying inefficiency effects. 